\title{
Pemberdayaan Ibu-Ibu Rumah Tangga di Mojomulyo, Sragen Kulon, Kabupaten Sragen melalui Usaha Telur Asin Aneka Rasa
}

\author{
Ratih Dewanti*, Ari Kusuma Wati dan Lilik Retna Kartikasari
}

Program Studi Peternakan, Fakultas Pertanian, Universitas Sebelas Maret, Surakarta, Indonesia

Diterima: 30 Maret 2020; Disetujui: 22 April 2020

\begin{abstract}
Abstrak
Telur asin sangat potensial untuk digunakan sebagai sumber protein hewani yang lebih murah dibandingkan daging. Telur asin aneka rasa belum populer di Kabupaten Sragen, sehingga memiliki prospek untuk bisa dikembangkan sebagai kuliner baru. Ibu-ibu Rumah Tangga di Mojomulyo, Sragen Kulon, Kabupaten Sragen yang tergabung dalam Arisan RT dan Dasawisma banyak mempunyai waktu luang. Permasalahan adalah mereka membutuhkan tambahan pendapatan dari usaha sendiri di rumah yang bisa sebagai sambilan selain tugas utamanya sebagai ibu rumah tangga. Telur asin aneka rasa merupakan telur asin yang kemudian diberikan tambahan rasa dapat berupa rasa soto, bawang, durian, kare, pedas, cokelat, dan strawberry. Diharapkan dengan diversifikasi telur asin ini, dapat menambah sasaran konsumen terutama anak-anak, dan anak-anak semakin mudah mendapatkan sumber protein hewani karena menyukai makan telur. Telur yang diasinkan dan dibuat aneka rasa adalah telur bebek, telur ayam dan puyuh. Pengabdian yang dilakukan meliputi kegiatan penyuluhan, praktek pembuatan telur asin, praktek pembuatan telur asin aneka rasa, pembukuan sederhana, pengemasan dan pemasaran produk. Pengabdian ini bermanfaat untuk menambah pengetahuan dan memanfaatkan waktu luang ibuibu rumah tangga di Mojomulyo. Melalui kegiatan ini, kemampuan dan keterampilan ibu-ibu rumah tangga di Mojomulyo mengalami peningkatan dan diharapkan mandiri secara ekonomis.
\end{abstract}

Kata kunci: aneka rasa; ibu-ibu rumah tangga; pemberdayaan; telur asin

\section{Empowerment of Housewives in Mojomulyo, Sragen Kulon, Sragen Regency through the Various Flavors Salted Egg Business}

\begin{abstract}
Salted eggs are very potential to be used as a cheaper source of animal protein compared to meat. Salted eggs of various flavors have not been popular in Sragen Regency, so they have the prospect of being developed as a new culinary. Housewives in Mojomulyo, Sragen Kulon, Sragen Regency who are members of the social gathering of neighborhoods have a lot of free time. The problem was that they need additional income from their own home business which could be part-time besides their main duties as a housewife. Salted eggs of various flavors were salted eggs which were given additional flavors, that was the taste of soto, onion, durian, curry, spicy, chocolate, and strawberry. It was hoped that with the diversification of salted eggs, it can increase the target of consumers, especially children, and children can more easily obtain sources of animal protein because they like eating eggs. Eggs that were salted and made of various flavors were duck eggs, chicken eggs and quail eggs. Community service activities include counseling activities, the practice of making salted eggs, the practice of making
\end{abstract}

\footnotetext{
* Corresponding author: ratihdewanti@staff.uns.ac.id
}

Cite this as: Dewanti, R., Wati, A. K., \& Kartikasari, L. K. (2020). Pemberdayaan Ibu-Ibu Rumah Tangga di Mojomulyo, Sragen Kulon, Kabupaten Sragen melalui Usaha Telur Asin Aneka Rasa. AgriHealth: Journal of Agri-food, Nutrition and Public Health, 1(1), 22-29. doi: http://dx.doi.org/10.20961/agrihealth.v1i1.40922 
salted eggs of various flavors, simple bookkeeping, packaging and marketing of products. This community service activities was useful for increasing the knowledge and utilizing their free time of housewives in Mojomulyo. Through this activity, the abilities and skills of housewives in Mojomulyo have increased and were expected to be economically independent.

Keywords: empowerment; housewives; salted egg; various flavor

\section{PENDAHULUAN}

Telur merupakan salah satu produk peternakan kaya zat gizi yang bermanfaat untuk manusia. Pengawetan telur biasanya dilakukan untuk memperpanjang masa simpan telur. Menurut Khasanah et al. (2010), telur sebagai bahan pangan sumber protein, lemak, vitamin, asam amino esensial yang dibutuhkan oleh tubuh manusia, akan tetapi dapat mudah rusak dan busuk. Salah satu langkah yang dapat dilakukan dan dapat menjadi usaha kecil prospektif adalah dengan cara pengawetan melalui pembuatan telur asin. Usaha telur asin dapat dijalani secara serius dan menguntungkan karena banyak disukai masyarakat. Menurut Latipah et al. (2017), telur asin merupakan salah satu produk olahan telur hasil peternakan yang banyak disukai oleh masyarakat, bertujuan untuk mengawetkan telur, mengurangi bau amis pada telur, penambah cita rasa, serta dapat memperbaiki kandungan gizi yang ada di dalam telur. Ganesan et al. (2014) menambahkan bahwa kandungan gizi yang terkandung di dalam telur yaitu air, protein, lemak, karbohidrat, asam lemak tidak jenuh serta beberapa vitamin dan mineral. Telur asin merupakan produk telur yang kaya nutrisi dan merupakan hasil olahan yang melibatkan proses pengasinan dan pemanasan.

Pangsa pasar telur asin dengan aneka rasa masih sangat terbuka lebar karena masih jarang. Telur asin aneka rasa adalah telur asin rasa bawang, cokelat, udang, pedas, stroberi dan aneka rasa lainnya. Pada umumnya telur asin yang sering dijumpai di pasar tradisional, warungwarung makan atau supermarket adalah telur asin yang mempunyai cita rasa khas yaitu asin dan gurih. Rasa asin pada telur berasal dari garam yang digunakan, konsentrasi garam yang digunakan akan mempengaruhi tingkat keasinan. Menurut Utomo (2006), jumlah larutan garam yang masuk akan menentukan rasa asin telur serta kemasiran kuning telur, sehingga semakin tua umur telur yang diasinkan semakin tinggi tingkat kemasiran kuning telur. Nasi rawon, pecel, atau nasi rames sangat cocok dipasangkan dengan telur asin rasa original (asin dan gurih), akan tetapi kalau telur asin dimakan tanpa ada pasangannya, akan lebih cocok dengan telur asin aneka rasa.

Inovasi baru dalam pembuatan telur asin aneka rasa setidaknya membuka sebuah peluang usaha baru yang cukup menjanjikan. Tujuan pembuatan telur asin aneka rasa adalah untuk menambah variasi baru produk telur asin yang sudah ada. Produk telur asin aneka rasa ini biasanya banyak dijumpai di daerah-daerah sentra industri pembuatan telur asin. Penggunaan bawang sebagai salah satu rasa telur asin digunakan untuk pengawet alami dan menambah cita rasa telur asin. Menurut Farida (2017), adanya sifat antioksidan dan antimikroba pada bawang putih maka dapat berfungsi sebagai bahan pengawet alami. Penggunaan bawang putih dalam pembuatan telur asin merupakan upaya pengawetan berlapis dan upaya penganekaragaman cita rasa sehingga dapat menambah peminat telur asin dan bertambah juga peluang usaha pedagang telur asin. Aneka rasa lain yang digunakan untuk pembuatan telur asin seperti cokelat dan stoberi digunakan sebagai upaya inovasi rasa dan meningkatkan kesukaan anak-anak terhadap telur asin.

Faktor pendukung lain usaha ini adalah rasa bosan pada anak-anak kita jika makan telur asin yang rasa original. Kenyataan ini tidak bisa dipungkiri dan ini adalah sebuah peluang untuk menyediakan bagi mereka makanan bergizi dengan rasa yang beraneka ragam seperti jajanan untuk anak-anak. Pilihan orang tua cerdas setelah membandingkan kesamaan harga, kandungan gizi dan keamanan produk tentu lebih memilih telur asin aneka rasa daripada jajanan snack yang belum jelas kandungan gizinya. Menurut BPOM (2013), kekurangan protein dapat menyebabkan terhambatnya pertumbuhan anak-anak, menurunkan daya tahan atau imunitas, serta timbulnya kejadian kwashiorkor dan marasmus.

Telur yang digunakan dalam pembuatan telur asin dapat berasal dari berbagai macam ternak ungags seperti itik, ayam, dan puyuh. Telur itik, telur ayam, dan telur puyuh ketiganya tinggi 
kandungan zat gizi yang bermanfaat untuk tubuh manusia. Menurut Octarisa et al. (2013), kandungan protein telur itik adalah $13,1 \%$, kalori dan lemak lebih tinggi dari pada telur ayam. Bobot dan ukuran telur itik rata-rata lebih besar dari pada telur ayam, berkisar antara 70-80 g per butir. Cangkang telur itik berwarna biru muda, sehingga telur itik sangat lazim diasinkan karena penetrasi garam ke dalam telur pada telur itik lebih mudah. Menurut Silondae dan Ulpah (2015), komposisi gizi dalam telur ayam terdiri dari protein $13 \%$, lemak $12 \%$, serta vitamin, dan mineral. Thomas et al. (2016) menambahkan bahwa telur puyuh mengandung protein kasar $13,30 \%$, serat kasar $0,63 \%$, ether extract $11,99 \%$, gross energy $1993 \mathrm{kcal} \mathrm{kg}^{-1}$. Telur asin memenuhi kriteria sebagai bahan makanan yang bernilai biologi tinggi karena proteinnya mudah dicerna dengan koefisien cerna sekitar 96\%. Dibandingkan dengan daging sapi, beras, dan jagung, nilai biologi protein telur itik paling tinggi karena mudah dicerna oleh tubuh, sehingga telur itik juga cocok dikonsumsi terutama oleh anak balita dengan catatan bukan penderita alergi makan telur.

Kabupaten Sragen merupakan kabupaten di wilayah Propinsi Jawa Tengah yang terletak paling timur dan berbatasan dengan Propinsi Jawa Timur. Permintaan telur asin di Sragen sangat tinggi. Kuliner telur asin aneka rasa belum ada di Kabupaten Sragen sehingga memiliki potensi yang besar untuk dikembangkan.

Mitra 1 dan 2 adalah kumpulan ibu-ibu rumah tangga di Kampung Mojomulyo yang tergabung dalam Dasawisma Barat dan Dasawisma Timur. Mereka biasanya antara jam 09.00-15.00 WIB sudah mempunyai waktu longgar sehingga dapat dimanfaatkan untuk mengolah dan memproduksi telur asin aneka rasa. Pemasaran hasil telur asin aneka rasa masih sangat terbuka luas karena merupakan kuliner baru di Kabupaten Sragen. Berdasarkan penjelasan diatas, kegiatan pemberdayaan sangat bermanfaat bagi ibu-ibu rumah tangga sehingga diharapkan setelah dilakukan pengabdian ini, ibu-ibu rumah tangga anggota dasawisma menjadi lebih berdaya, mendapatkan penghasilan tambahan dan usaha akan tetap terus berjalan walaupun pengabdian telah selesai dilakukan. Saat ini secara keseluruhan Dasawisma barat dan timur beranggotakan sekitar 30 orang yang mempunyai rentangan umur antara 25 sampai 65 tahun. Permasalahan yang pertama adalah masalah kurangnya pendapatan dan lapangan kerja. Permasalahan kedua adalah masalah pemanfaatan waktu luang. Permasalahan ketiga adalah belum adanya produk telur asin aneka rasa di pasaran Kabupaten Sragen.

Solusi dengan adanya program ini difokuskan kepada pemberdayaan ibu-ibu rumah tangga dengan keterampilan pembuatan telur asin aneka rasa. Luaran yang diharapkan guna membentuk ibu-ibu Dasawisma sebanyak 30 orang mempunyai kemampuan membuat telur asin aneka rasa dengan harapan bisa melakukan usaha sendiri di rumahnya yang kemudian menjadi mata pencaharian sampingan dan mendapatkan penghasilan tambahan.

\section{BAHAN DAN METODE}

Pengabdian dilakukan di kediaman ibu RT 02/RW 09 Ibu Sugiman, Mojomulyo, Sragen Kulon, Sragen Tahun 2019. Jumlah total ibu-ibu PKK RT 02/RW 09 adalah 40 orang. Berdasarkan permasalahan di atas, beberapa alternatif solusi ditawarkan kepada Ibu-ibu rumah tangga di Mojomulyo, solusi dan kegiatan yang ditawarkan dapat dilihat pada Tabel 1. Selain itu sebelum penyuluhan dan praktek dilakukan pre-test dan setelah selesai kegiatan dilakukan post-test.

Tabel 1. Solusi dan kegiatan yang ditawarkan

Solusi Kegiatan

Pemberdayaan Ibu-ibu rumah tangga melalui 1. Melakukan Pendampingan pembuatan telur Keterampilan pembuatan telur asin aneka rasa. asin aneka rasa.

Keterampilan yang diberikan meliputi 2. Menyediakan telur bebek, ayam dan puyuh, pembuatan telur asin, pemilihan telur bebek yang baik, pembuatan bumbu, penyuntikan rasa, 3. Pelatihan pembukuan, pengemasan dan pengemasan dan pemasaran. pemasaran. 


\section{Langkah-langkah pembuatan telur asin aneka rasa}

Penyiapan alat dan bahan yang diperlukan antara lain jarum suntik, bahan perasa (coklat bubuk, bawang, udang), bahan penutup lubang bekas suntikan (tusuk gigi), telur bebek terpilih, garam, batu bata halus, blender, serbet, baskom (ember besar), stempel, dan ayakan. Memeriksa kondisi telur yang akan diasinkan meliputi kondisi fisik telur seperti retak atau tidak dan juga ketebalan kulit telur. Membersihkan kulit telur itik atau puyuh yang akan diasinkan. Membuat adonan atau medium pengasinan yang terdiri dari batu bata halus dan larutan garam. Pemeraman telur selama 15 hari (lama pemeraman menentukan kadar keasinan yang diinginkan). Pembongkaran telur yang telah diperam kemudian dibersihkan. Penyuntikan telur dengan ekstrak rasa yang dipilih. Penutupan bekas lubang jarum suntik dengan tusuk gigi. Pemasakan atau pematangan telur dengan cara dikukus selama kurang lebih 60 menit (untuk mengurangi risiko pecah). Pemberian stempel nama usaha dan cap rasa.

\section{Pemasaran produk}

Pemasaran merupakan kunci sukses sebuah wirausaha dan ujung tombak kegiatan usaha produksi. Kegiatan pemasaran telur asin aneka rasa dapat dilakukan melalui penyebaran pamflet atau brosur yang dipasang di tempat-tempat umum dan strategis. Bentuk kegiatan pemasaran lain yaitu dengan mekalukan promosi secara word of mouth (metode pemasaran dari mulut ke mulut), dengan memberikan tester gratis untuk percobaan, menitipkan langsung di warungwarung makan, pasar swalayan, koperasi sekolah atau sekolahan yang menerapkan program belajar full day. Pangsa pasar dari produk telur asin aneka rasa ini sangat luas hanya diperlukan inovasi dan pengelolaan yang lebih profesional untuk meningkatkan jumlah penjualan. Kegiatan pemasaran

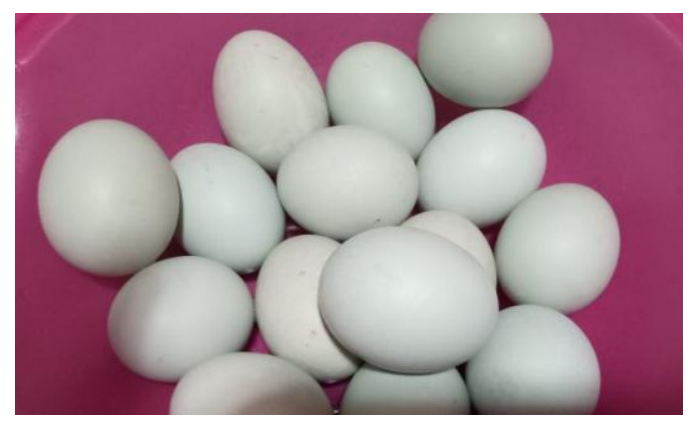

Gambar 1. Contoh telur bebek pilihan produk harus dilakukan lebih gencar dengan berbagai media promosi agar masyarakat mengetahui bahwa ada sebuah produk telur asin aneka rasa. Kegiatan pemasaran akan lebih efektif kalau ditunjang dengan data pendukung seperti izin dari dinas kesehatan dan dinas perdagangan. Apabila kegiatan usaha pembuatan telur asin sudah berjalan maka perlu untuk menjaga kontinyuitas produk yaitu dengan menjalin kerjasama kemitraan antara peternak telur itik, pembuat atau pengusaha telur asin serta pemerintah, sehingga pengembangan produk bisa lebih cepat berkembang.

\section{HASIL DAN PEMBAHASAN}

Pengabdian dilakukan kepada ibu-ibu anggota PKK RT 02/RW 09 Mojomulyo, Sragen Kulon Kabupaten Sragen. Hasil yang dicapai yaitu telah dilakukan introduksi bahan dan alat untuk pembuatan telur asin (baskom, spuit, ember, sendok, mangkok, kompor) serta sudah dilakukan penyuluhan dan pelatihan pembuatan telur asin. Hasil kuesioner (pre-test dan post-test) menunjukkan bahwa telah terjadi peningkatan hasil sesudah penyuluhan dibandingkan sebelum penyuluhan. Telur yang digunakan adalah telur bebek, ayam dan puyuh. Rasa yang disuntikkan meliputi rasa stroberi, cokelat, bawang, soto, durian, pedas dan lain-lain. Rasa pada telur puyuh diperoleh dengan metode perendaman bukan penyuntikan karena bentuk telur yang kecil dan jumlahnya banyak. Jumlah telur bebek yang digunakan untuk pelatihan adalah 100 butir, telur ayam kampung 50 butir dan telur puyuh 200 butir.

\section{Kegiatan penyuluhan}

Bahan-bahan yang digunakan dalam pelatihan pembuatan telur asin disajikan pada Gambar 1, Gambar 2, Gambar 3 dan Gambar 4, sedangkan proses pembuatan telur asin disajikan pada Gambar 5 dan Gambar 6.

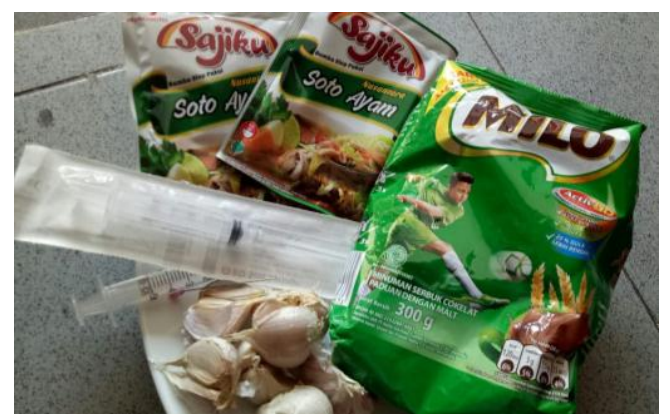

Gambar 2. Contoh bahan perasa dan alat suntik 


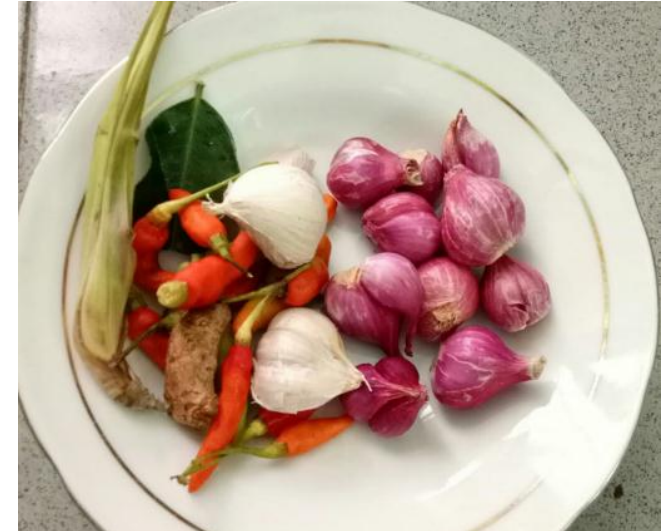

Gambar 3. Bumbu dapur

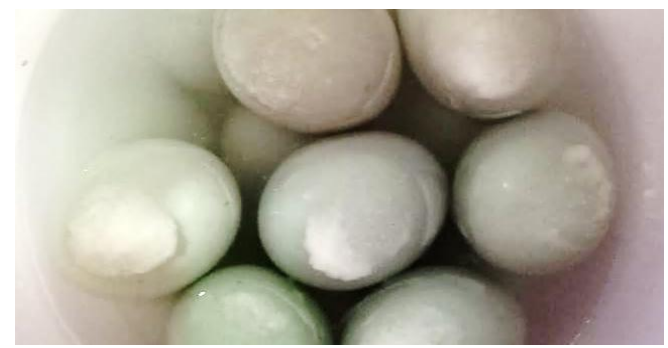

Gambar 5. Proses pengasinan telur
Kegiatan penyuluhan dilakukan untuk mentransfer Iptek (ilmu pengetahuan dan teknologi) dari tim pengabdian masyarakat kepada kelompok sasaran untuk memecahkan persoalan yang dihadapi. Penyuluhan dihadiri 28 ibu-ibu PKK RT 02/RW 09. Menurut Amanah (2007), penyuluhan merupakan ilmu dan gerakan transformasi masyarakat melalui pengembangan potensi yang dimiliki dengan pendekatan edukasi, melakukan upaya penyelesaian masalah, menuju

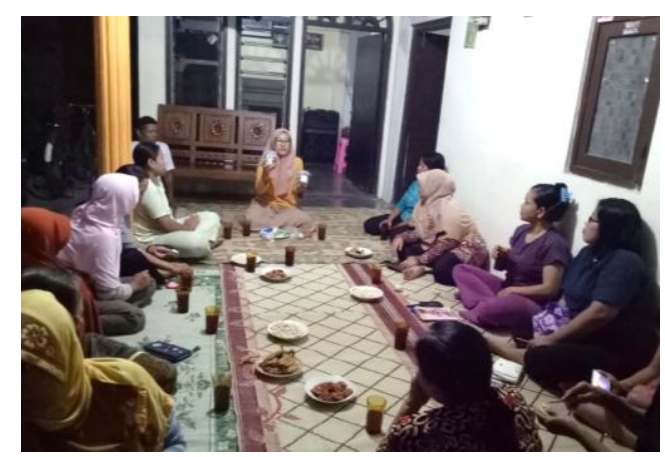

Gambar 7. Penyuluhan pembuatan telur asin kepada PKK Dasawisma 1

Hasil pre-test dan post-test yang disajikan pada Tabel 2 menunjukkan bahwa dari segi umur peserta pelatihan dan penyuluhan berada pada

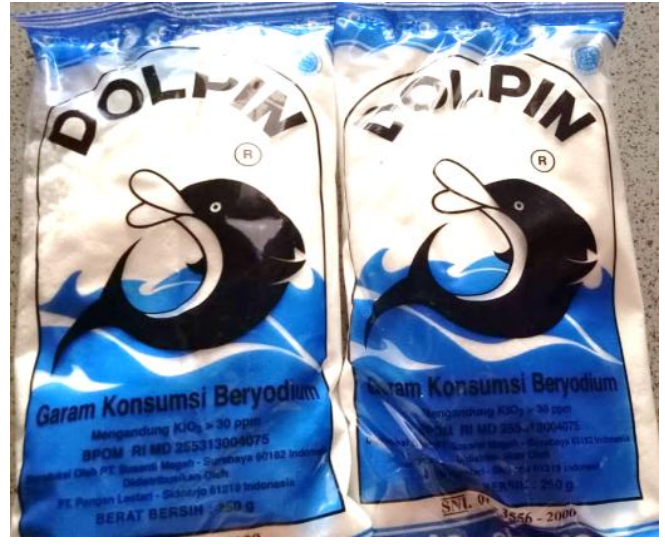

Gambar 4. Garam halus

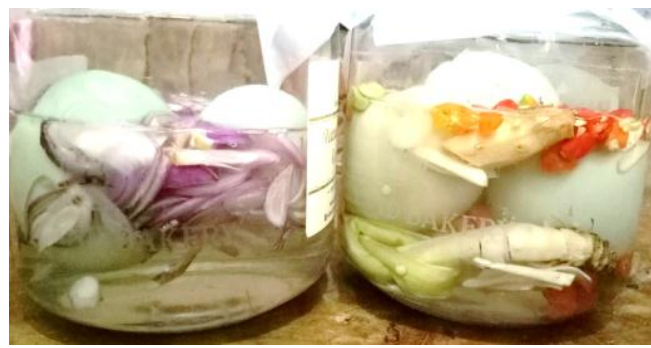

Gambar 6. Contoh penambahan rasa model rendam

tatanan kehidupan yang lebih bermutu dan bermartabat (Gambar 7 dan Gambar 8).

Peningkatan pengetahuan merupakan satu aspek mendasar yang dijadikan parameter keberhasilan penyuluhan. Pengukuran pengetahuan peserta sebelum dan sesudah penyuluhan merupakan salah satu cara evaluasi terhadap efektivitas peran dan kegiatan penyuluhan. Oleh karena itu, dalam kegiatan ini dilakukan pre-test dan post-test untuk mengetahui pengetahuan dan keterampilan peserta.

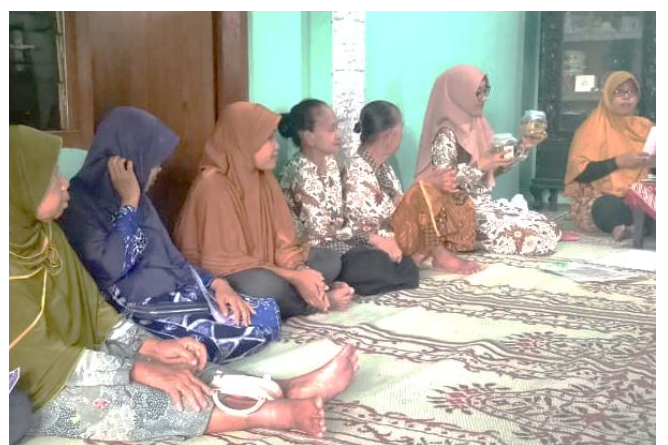

Gambar 8. Penyuluhan pembuatan telur asin kepada PKK Dasawisma 2

rentang 18-60 tahun. Ibu-ibu PKK secara fisik sangat mampu untuk melakukan pekerjaan usaha wirausaha telur asin dengan maksimal. Karak- 
teristik peserta penyuluhan seluruhnya adalah ibuibu PKK. Sebelum dan sesudah penyuluhan dilakukan pembagian quesioner.

Berdasarkan hasil kuesioner didapatkan data bahwa setelah penyuluhan tingkat jawaban yang betul mengalami kenaikan yang cukup signifikan dari 258 menjadi 321 poin. Hal ini memberikan gambaran bahwa dengan diadakannya penyuluhan ternyata sangat dapat meningkatkan pengetahuan dan wawasan ibu-ibu PKK tentang pembuatan telur asin aneka rasa. Bahkan setelah penyuluhan sebagian besar mendapatkan nilai penuh (betul semua) yaitu 12 point. Ibu-ibu dengan umur lebih muda (rentangan umur 18-40 tahun) cenderung memiliki nilai yang lebih tinggi dibandingkan ibu-ibu dengan usia senja 50-60 tahun. Selain kegiatan tersebut, juga melakukan pelatihan pembukuan sederhana (pemasukan, pengeluaran, saldo dan keterangan) sehingga keuangan terorganisir dengan baik. Pembukuan keuangan secara sederhana telah dibuat oleh kedua mitra. Pelatihan pemasaran yaitu masih pemasaran secara langsung ke konsumen (kantor, sekolah dan pasar).

Tabel 2. Hasil kuesioner (pre-test dan post-test) penyuluhan pembuatan telur asin aneka rasa

\begin{tabular}{|c|c|c|c|c|}
\hline No & Nama (inisial) & Umur & Nilai sebelum penyuluhan & Nilai sesudah penyuluhan \\
\hline 1. & $\mathrm{An}$ & 31 & 7 & 12 \\
\hline 2. & $\mathrm{Rh}$ & 41 & 12 & 12 \\
\hline 3. & Dw & 18 & 8 & 12 \\
\hline 4. & $\mathrm{Rp}$ & 27 & 7 & 11 \\
\hline 5. & Sn & 47 & 10 & 10 \\
\hline 6. & $\mathrm{Ak}$ & 50 & 10 & 12 \\
\hline 7. & $\mathrm{Ik}$ & 45 & 10 & 12 \\
\hline 8. & Mn & 55 & 9 & 11 \\
\hline 9. & $\mathrm{Sr}$ & 42 & 11 & 12 \\
\hline 10. & Dr & 43 & 10 & 12 \\
\hline 11. & Kn & 40 & 10 & 11 \\
\hline 12. & $\mathrm{Rn}$ & 45 & 11 & 12 \\
\hline 13. & Dr & 40 & 8 & 11 \\
\hline 14. & Ac & 39 & 7 & 11 \\
\hline 15. & $\mathrm{Wr}$ & 41 & 7 & 11 \\
\hline 16. & $\mathrm{Sn}$ & 50 & 11 & 12 \\
\hline 17. & $\mathrm{Mr}$ & 49 & 11 & 12 \\
\hline 18. & Af & 40 & 11 & 12 \\
\hline 19. & $\mathrm{Ar}$ & 43 & 11 & 12 \\
\hline 20. & Rt & 37 & 9 & 11 \\
\hline 21. & Ip & 40 & 10 & 12 \\
\hline 22. & Ay & 30 & 10 & 12 \\
\hline 23. & $\mathrm{Wr}$ & 60 & 7 & 9 \\
\hline 24. & $\mathrm{Wd}$ & 57 & 5 & 10 \\
\hline 25. & $\mathrm{Su}$ & 59 & 6 & 11 \\
\hline 26. & Ss & 36 & 10 & 12 \\
\hline 27. & Sk & 45 & 10 & 12 \\
\hline 28. & $\mathrm{Bm}$ & 37 & 10 & 12 \\
\hline & Jumlah & & 258 & 321 \\
\hline
\end{tabular}

Keterangan: Nilai maksimal 12 (apabila jawaban benar 100\%)

\section{Monitoring, pendampingan pembuatan dan produksi telur asin}

Dalam suatu kegiatan, monitoring dan pendampingan sangat diperlukan untuk mengetahui sejauh mana kegiatan telah berjalan, apakah sesuai dengan yang direncanakan atau tidak dan juga untuk mengetahui kendala dan hambatan yang timbul. Adanya monitoring dan pendampingan kegiatan bisa dikontrol dan apabila masalah yang menghambat ditemui, bisa segera dilakukan tindakan untuk mengatasi masalah tersebut. Monitoring dan pendampingan pembuatan telur asin dilakukan mulai dari penyu- 
luhan, pemilihan telur yang baik dan segar, pembuatan telur asin, penyimpanan, pembuatan telur asin aneka rasa, pengemasan dan pemasaran. Pendampingan dan monitoring pembuatan telur asin dilakukan setiap satu minggu sekali.

\section{Dampak pengabdian}

Setelah mendapatkan pelatihan dan penyuluhan tentang pembuatan telur asin aneka rasa, ibu-ibu PKK di Kampung Mojomulyo mengalami peningkatan dan tambahan keterampilan. Kedua mitra ingin mencoba usaha lebih serius, sehingga usaha ini menjadi berkelanjutan. Sedikit kendala adalah ibu-ibu banyak yang kurang sabar dalam penyuntikan telur, sehingga diperlukan kebiasaan. Ibu-ibu PKK juga tertarik ingin memproduksi telur sendiri dengan pemeliharaan bebek. Tidak hanya dampak pada ibu-ibu PKK Kampung Mojomulyo saja akan tetapi ibu-ibu PKK dari kampung dan RW sebelah juga tertarik untuk membuat telur asin aneka rasa, sehingga dampak pengabdian begitu luas dan sangat bermanfaat. Sedikit kendala hanya pada proses memberikan rasa dengan model injek atau suntik telur, sangat memerlukan ketelatenan.

\section{KESIMPULAN}

Kemampuan dan keterampilan Ibu-ibu PKK Mojomulyo meningkat dan diharapkan mandiri secara ekonomis. Introduksi dan pemanfaatan bahan dan peralatan berjalan dengan sangat baik. Produksi telur asin aneka rasa yang berkelanjutan, kemampuan dalam pembukuan dan pemasaran produk. Pembukuan keuangan secara sederhana telah dibuat oleh kedua mitra.

\section{UCAPAN TERIMA KASIH}

Ucapan terima kasih disampaikan kepada Ibuibu PKK Mojomulyo, Kelurahan Sragen Kulon, Kabupaten Sragen yang telah bersedia menjadi mitra dan mendukung kegiatan pengabdian ini.

\section{DAFTAR PUSTAKA}

Amanah, S. (2007). Makna Penyuluhan dan Transformasi Perilaku Manusia. Jurnal Penyuluhan. 3(1), 63-67. https://doi.org/10.2 5015/penyuluhan.v3i1.2152.

Badan Pengawas Obat dan Makanan, [BPOM]. (2013). Pedoman pangan jajanan anak sekolah untuk pencapaian gizi seimbang. Jakarta: Direktorat Standardisasi Produk
Pangan Deputi Bidang Pengawasan Keamanan Pangan dan Bahan Berbahaya. Tersedia dari http://standarpangan.pom.go.id/dokumen/ped oman/Buku_Pedoman_PJAS_untuk_Pencapai an_Gizi_Seimbang__Orang_Tua_Guru_Pe ngelola_Kantin_.pdf

Ganesan, P., Kaewmanee, T., Benjakul, S., \& Baharin, B. S. (2014). Comparative Study on the Nutritional Value of Pidan and Salted Duck Egg. Korean Journal for Food Science of Animal Resources, 34, 1-6. https://doi.org/ 10.5851/kosfa.2014.34.1.1

Faridah, A. (2017). Pengaruh Penambahan Bawang Putih Terhadap Kualitas Telur Asin. Jurnal Pendidikan dan Keluarga, 9(1), 1-9. https://doi.org/10.24036/jpk/vol9-iss1/41

Khasanah, L. U., Anandit, B. K., \& Saputro, B. A. (2010). Pengaruh Perendaman dalam Ekstrak Teh Hijau terhadap Umur Simpan Telur Asin. Jurnal Teknologi Hasil Pertanian, 3(2), 111121. https://jurnal.uns.ac.id/ilmupangan/articl e/view/13640

Latipah, I. R., Utami, M. M. D., \& Sanyoto, J. I. (2017). Pengaruh konsentrasi garam dan umur telur terhadap tingkat kesukaan konsumen telur asin. Jurnal Imu Peternakan Terapan, 1(1), 1-7. https://doi.org/10.25047/jipt.v1i1.5 30

Octarisa, R., R. S. S. Santoso, \& Sukardi. (2013). Pengaruh perbandingan tepung tapioka dengan telur asin dan lama pengukusan pada pembuatan kerupuk telur terhadap kadar garam dan kesukaan rasa. Jurnal Ilmiah Peternakan, 1(1), 157-162. Tersedia dari https ://onesearch.id/Record/IOS1477.article-565

Silondae, H., \& Ulpah, A. (2015). Peningkatan Kualitas Telur Ayam Ras dengan Perendaman dalam Larutan Teh. Jurnal Penelitian Pascapanen Pertanian, 12(3), 124-128. Tersedia dari https://www.researchgate.net/ publication/312297488_Improving_the_Eggs _Quality_to_Maintain_on_Tea_Solution

Thomas, K. S., Jagatheesan, P. N. R., Reetha, T. L., \& Rajendran, D. (2016). Nutrient Composition of Japanese Quails Egg. Inter. J. Scie, Envirom. And Tech, 5(3), 1293-1295. Tersedia dari http://www.ijset.net/journal/100 1.pdf 
Utomo, B. (2006). Pengaruh Umur Telur terhadap Kualitas Kemasiran Telur Asin yang Diasin selama 14 hari. Skripsi. Institut
Pertanian Bogor. Bogor. Tersedia dari https://repository.ipb.ac.id/handle/123456789/ 3319 